MARTIN BERG, IDA LIDEGRAN, ULRIKA SCHMAUCH, GLENN SJÖSTRAND \& ZHANNA KRAVCHENKO

\title{
Digital sociologi
}

\section{Att undervisa i sociologi under en pandemi}

I SOCIOLOGISK FORSKNING har undervisning och lärande tidigare diskuterats på flera sätt. Ämnet har bland annat behandlats i forskningsartiklar som undersökt skolbarns välbefinnande och utbildningsresultat (Aytar \& Mella 2012), hinder för tillgång till högre utbildning (Ismail 2011), professionsutmaningar inom gymnasieutbildningen (Bruno 2012) och strukturella bestämningsfaktorer för akademiska karriärer (Behtoui 2017). Den sociologiska forskningspraktikens nära koppling till ämnets pedagogiska praktik har också medfört att personliga undervisningserfarenheter behandlats i olika texter (se specialnumret "Sociologi i tiden": Hansen, Johansson, Kollind m.fl. 1997).

Tidskriftens redaktion skulle framöver gärna se fler artiklar som behandlar frågor om undervisning och lärande inom sociologiämnet. Vi välkomnar därför sociologikollegor att inkomma med förslag till sådana artiklar eller färdiga manus. Det skulle kunna vara texter om hur vår praktik som sociologer påverkar vårt sätt att undervisa, hur sociologisk forskning omsätts i undervisning, hur olika pedagogiska metoder och material kan användas i sociologiundervisningen eller hur samhälleliga processer och strukturer påverkar vad som händer i klassrummet. Vi tror att sådana reflektioner med fördel skulle kunna ta sin utgångspunkt i utbildningssociologi och den svenska sociologins reflekterande tradition.

Som ett första steg mot att ge utrymme åt denna typ av artiklar publicerar vi i detta nummer ett samtal om hur undervisningen i sociologi har påverkats av övergången till digital undervisning under covid-19-pandemin. Vi bad fyra sociologikollegor, verksamma vid olika svenska lärosäten, att svara på några frågor utifrån sina erfarenheter som lärare, utbildningssamordnare och forskare. De medverkande är Martin Berg, professor i medieteknik och docent i sociologi vid Malmö universitet, som forskar om digital sociologi med särskilt fokus på kritiska studier av algoritmer och automatiseringsprocesser; Ida Lidegran, docent i utbildningssociologi vid Uppsala universitet, som ingår i Forskningsgruppen för utbildnings- och kultursociologi (SEC) och forskar om elitutbildningar och familjers utbildningsstrategier, migranters möte med det svenska utbildningssystemet samt utbildning och covid-19; Ulrika Schmauch, lektor i sociologi vid Umeå universitet, vars forskning handlar om social ojämlikhet i allmänhet och om ras, plats och kön i synnerhet; samt Glenn Sjöstrand, prefekt för Institutionen för 
samhällsstudier vid Linnéuniversitetet i Växjö, vars forskning i huvudsak är inriktad mot professionsstudier och särskilt ingenjörers professionella utveckling, men som även forskar om digital transformation, miljö och välfärdsfrågor.

I texten reflekterar de medverkande över sina undervisningserfarenheter. De förhåller sig till specifika kurser, exempelvis en masterskurs om befintliga och framtida medieteknologiers sociala, ekonomiska, kulturella samt tekniska uttryck och förutsättningar (Martin Berg) eller kurser i utbildningssociologi och vid lärarutbildningarna (Ida Lidegran). I Ulrika Schmauchs och Glenn Sjöstrands fall knyts reflektionerna även till mer allmänna erfarenheter av undervisning på olika kurser, på olika program och vid olika fakulteter. Samtliga medverkande arbetade med texten i ett gemensamt dokument online där de kunde ändra och göra tillägg i sina svar. Zhanna Kravchenko i Sociologisk Forsknings redaktion anordnade och modererade samtalet. Den slutliga texten färdigställdes den 28 december 2021.

\section{Utifrån vad vi som sociologer vet om mänsklig interaktion, hur den formas av olika sammanhang och hur vi som människor formas av den - vad kan vi säga om digital undervisning?}

Ida Lidegran: I mitt senaste studentmöte när jag loggade in i Zoom för att undervisa möttes jag av en alien. Uppenbart är att en hel del av det vi tar för givet i den fysiska interaktionen förändras genom den digitala undervisningen. Att möta en alien i Zoom i stället för en människa i en lärosal innebär förstås att flera delar av interaktionen blir kraftigt beskurna och att mötet blir annorlunda. Ansiktsuttryck är svårare att uppfatta på skärmen, och är skärmen svart eller enbart visar en bild på en alien försvinner mimiken helt. I de fall deltagarna stängt av ljudet finns heller inga stöttande småord och ljud som hummanden i kommunikationen. Detta leder ibland till en överdriven interaktion. Vi viftar, nickar, håller upp tummar och så vidare. Skulle vi överföra denna i digitala sammanhang nödvändigt överdrivna interaktion till det fysiska mötet skulle situationen troligen upplevas som konstig och besvärande eller rent av komisk. Detta "zoombeteende" består inte bara i reducering av interaktionens innehåll och förstärkning av vissa uttryck. Det öppnar också för möjligheter till nya former av identitetsskapande. Att logga in som en alien ger en friheten att visa upp sig på helt nya sätt och utforska olika roller i kommunikativa sammanhang. Här kan man dock fråga sig om inte lärare, med sitt bagage och sina erfarenheter av att undervisa IRL ${ }^{1}$ i lärosalar, är de som har svårast att anpassa sig till och se möjligheterna i denna nya typ av interaktion. Studenter är ofta från en yngre generation och har betydligt större vana och erfarenhet av att röra sig i digitala rum.

1 IRL betyder in real life, "i verkliga livet". Uttrycket används i internetsammanhang för att beskriva interaktion i den fysiska världen. Red. anm. 
Martin Berg: Intressant iakttagelse! Jag tycker att det du skriver väcker en del tankar om vad vi annars tar för givet i klassrummet och i andra sammanhang som inte medieras genom Zoom. Vilka är det vi ser bland studenterna och vilken grad av lekfullhet öppnar vi för och erkänner i ett sådant möte? Det här väcker frågor om hur vi förstår och begreppsliggör det digitala. Tanken att vi skulle ha att göra med en väsensskild rumslighet - med allt vad det innebär för möjligheterna att tänja på identitetsgränser, att lämna det kroppsliga därhän och så vidare - ligger ofta nära till hands, men denna tanke har inte alltid någon egentlig bäring i dag (se till exempel Berg 2008, 2011, 2012, 2014). För varje år som går känner jag mig mer och mer som en stofil, men jag brukar trösta mig med att jag trots allt har ganska bra koll på digitala medier av olika slag. Trots min självupplevda digitala spänstighet är jag dock alltid hopplöst efter. Det tror jag är en viktig faktor att ta hänsyn till när vi talar om dessa frågor och när vi resonerar kring digital undervisning. Den upplevs sannolikt som väldigt digital och kanske annorlunda för oss som undervisar, men vi kan fråga oss om så verkligen är fallet med studenter och vad som i så fall utgör det nya.

För många av studenterna är vardagslivet redan från början digitalt på ett sätt som kan verka främmande för den som är mer, hur ska jag säga, analogt lagd. Det betyder så klart inte att de senaste 18-19 månaderna av zoominarier och liknande inte har inneburit något särskilt för studenterna, men som jag skrev ovan måste vi fundera på vad som är nytt eller annorlunda. För studenterna är det kanske främst livet kring studierna som ter sig annorlunda. Jag har funderat en del på vad det innebär att vi ständigt ser oss själva tala och lyssna på Zoom (eller när det gäller studenter: att äta frukost eller lunch med ansiktet nära kameran). Har vi här att göra med en ny form av medierad självmedvetenhet och vilken betydelse får den i så fall för både lärare och studenter?

Där tror jag vi har en ingång till fortsatta samtal om vad digital undervisning innebär: nämligen att det digitala inte är ett rum, utan ett gränssnitt där vi möter både varandra och oss själva. Kanske innebär digital undervisning också närvaron av en massa andra aktörer som annars inte har en naturlig plats vare sig bakom, framför eller på och under katedern - det sistnämnda kan vara relevant i dessa tider. Hundar som pruttar mitt under en föreläsning, katter som somnar på tangentbordet, partners som brygger kaffe: alla dessa helt materiella företeelser är ju ganska viktiga delar av den där digitala undervisningsverkligheten. Vilken roll tror ni att de här små observationerna kan ha för studenter som loggar in som en alien eller som någon annan varelse? Vad betyder det för oss som pedagoger?

Glenn Sjöstrand: Martin berör hur digitaliseringen av undervisningen tänjer identitetsgränser. Med det i åtanke hade jag häromdagen en föreläsning i hybridform för både svenska och internationella ingenjörsstudenter där ungefär hälften var digitalt uppkopplade och hälften var i klassrummet. Temat var teknologin i samhället och innovationsspridning. Jag upplevde det som väldigt svårt att skapa social responsivitet i denna situation. Studenterna uppvisade litet engagemang kring detta tema och det gällde särskilt de studenter som var digitalt uppkopplade med avslagen kamera. 
Lärarnas förväntningar på vad studenter ska göra har förändrats med den digitala undervisningen, tror jag. Det jag i första hand tänker på är i vilken utsträckning de förväntas vara aktiva och hur de förväntas interagera med oss och kurskamraterna via digitala medier, men jag tänker också på vilka känslomässiga reaktioner (förtroende, heder, solidaritet med mera) som uppstår som en följd av mediet. Även om vi säger att de ska ha sina kameror påslagna och sina mikrofoner avstängda när de inte pratar, så påverkar det inte deras beteende i någon större utsträckning. Gruppdiskussioner i Zoom fungerar något bättre, enligt min erfarenhet. Men det kan förstås finnas olika skäl till att interaktionerna i undervisningssituationer har förändrats med digitaliseringen.

Randall Collins (2020) resonerar om pandemins inverkan på ansikte mot ansikteinteraktionen. Han menar att den digitala undervisningen inte kan ersätta den fysiska klassrumsinteraktionen, men däremot komplettera den. Utifrån sin teori om interaktionsritualkedjor (interaction ritual chains) identifierar Collins fyra olika mekanismer som påverkar graden av solidaritet som uppstår i interaktionen: 1. Vår möjlighet att vara närvarande, som påverkas av den fysiska närheten till varandra i vad vi ser, hör och kan uppfatta med våra övriga sinnen. Det gäller inte minst gester och ansiktsuttryck, som ger ledtrådar till huruvida någon förstått eller är konfunderad över undervisningsinnehåll och argumentation. 2. Ömsesidigt uppmärksamhetsfokus, som riktar vårt medvetande mot samma fråga. Känslan av intersubjektivitet och möjligheten att agera samordnat och med likartade gester påverkar den gemensamma förståelsen av vad man gör och ska göra. 3. Gemensamma känslor och stämningar, oavsett vilka de är. 4. Rytmisk samordning i röst, tal, turtagning och kropp, som bidrar till att studenter och lärare begriper situationen.

Den digitala undervisningen gör det svårt att åstadkomma allt detta på ett sätt som underlättar måluppfyllelsen i kursen. Det är svårt att uppnå synkronicitet med andra genom en skärm full av ansikten eller svarta rutor med bristande återkoppling i realtid och med svårigheter att uppfatta nyanser i ansikts- och kroppsuttryck.

Collins menar att närvaron i interaktionen ökar den återkoppling som vi ger varandra när förutsättningarna är de rätta. Ju mer vi tar hänsyn till varandra och uppfyller de fyra mekanismerna ovan, desto mer samordnade blir deltagarna - samtidigt som gemensamma känslor ökar det ömsesidiga fokuset. Effekterna av framgångsrik interaktion enligt ovan är ökad social solidaritet (att individer känner sig och ser varandra som gruppmedlemmar), ökad känslomässig energi med ökat självförtroende, ökad entusiasm och ett mer proaktivt förhållningssätt, där gruppens kollektiva symboler framhävs (såsom mål, idéer eller objekt som markerar tillhörighet) tillsammans med moraliska övertygelser om vad som är rätt och fel. Om vi med hjälp av digital undervisningsteknologi och all vår pedagogiska förmåga kan stärka känslan av gemenskap med hjälp av de fyra mekanismerna skulle vi alltså trots allt kunna upprätthålla en god undervisning digitalt.

Den digitala undervisningen försvåras när man inte ser studenternas ansikten, men åsynen av ens eget ansikte på skärmen kan också vara stressande och arbetsam för hjärnan att analysera. Något som kan verka avstressande och lugnande, och som kan 
bidra till att upprätthålla en adekvat intrycksstyrning i självframställningen, för att tala med Goffman (2020[1959]), är att stänga av bilden på sin egen kamera så att endast åhörarna kan se den.

Nåväl, föreläsningen för ingenjörerna var jag inte särskilt nöjd med som lärare, men studenterna verkar ha tagit emot informationen väl. De frågor som uppkom kunde hanteras genom chattfunktionen på Zoom liksom direkta frågor i klassrummet. Det är betydligt mer arbetsamt, upplever jag, att hybridundervisa än att undervisa antingen digitalt eller i klassrummet. Förhoppningsvis kan våra gemensamma erfarenheter $\mathrm{i}$ förlängningen leda fram till en arbetsbesparande digital undervisning som samtidigt håller god kvalitet.

Ulrika Schmauch: Intressant! För att fortsätta tänka med Goffman har jag själv valt att spela in föreläsningar just för att det är så svårt att behålla den professionella masken när jag inte får någon som helst respons. Vid seminarier har vi krävt att kamerorna ska vara påslagna just för att underlätta diskussioner. Trots att jag försökt säga att det är viktigt att se vilka som är med på seminariet därför att det är examinerande och därför att jag som myndighetsperson behöver veta vilka som är i zoomrummet, har flera bilder varit svarta.

När jag på en kurs hade en student med hörselnedsättning som behövde se ansikten för att kunna läsa av vad folk sade var alla kamerorna påslagna. De som hade problem med sina kameror kopplade in sig på sina telefoner, utan att jag behövde kommentera det. Att anpassa sig till formella krav verkade alltså vara mindre viktigt än att möjliggöra för klasskamrater att vara delaktiga och tillgodogöra sig kursen. För mig, som uppmanat studenter att se universitetet som sitt och sina kurser som något de ska använda för att lära sig och varandra, var det förstås en fin upplevelse. Men polletten trillade ner för mig när jag bytte kontext som lärare. Jag tänker mig att det är lite samma fenomen som när lärare uppmanas att åka och undervisa utomlands - nya erfarenheter och perspektiv får oss att se nya saker. Den främsta lärdomen av digital undervisning blir då inte att man fått tillfälle att sätta sig in i tekniska system eller lärt sig när det är lämpligt att sluta dela skärm eller att skicka in studenter i breakout rooms ${ }^{2}$, utan att man fătt syn på det där självklara som man inte ens visste att man inte visste.

\section{Vilka lärdomar går att dra från digital undervisning i sociologi? Finns det några sociologiska frågor som är särskilt svåra att förmedla och diskutera digitalt?}

Ulrika Schmauch: Sociologi är i hög grad ett ämne man kan läsa sig till, lyssna sig till, skriva sig till. Empiriska fall och teoretiska traditioner är enligt min erfarenhet relativt enkla att förmedla och diskutera digitalt. Inspelade föreläsningar och seminarier där nervösa studenter kan sitta vid sina trygga köksbord och klappa ett lent husdjur ger studenter större förutsättningar att ta till sig kursens innehåll på sina egna villkor.

2 Funktion i videokonferensprogrammet Zoom som gör det möjligt att tillfälligt dela upp deltagarna i mindre grupper. Red. anm. 
Samtidigt är sociologi ett ämne som på många sätt relaterar till känslor, upplevelser och erfarenheter, och dessa är en stor tillgång när mer avancerade resonemang kring olika teoretiska begrepp behöver konkretiseras. Att som lärare utgå ifrån känslor, erfarenheter och upplevelser som studenterna berättar om är mer komplicerat i digital undervisning, eftersom möjligheterna att läsa av reaktioner hos studenterna är mindre. Det är också svårare att följa upp reaktioner mer informellt under raster och att läsa av stämningar mellan studenter efter undervisningstillfällena. Det är visserligen möjligt att föra samtal om liknande teman även digitalt, men det finns alltså en risk för att de förblir teoretiska och att det tar längre tid för studenterna att göra kunskapen till sin.

Martin Berg: Ulrika fångar en viktig dubbelhet i innebörden av att undervisa i sociologi digitalt. Jag kommer att tänka på vilken betydelse som egentligen läggs i "digital undervisning i sociologi". Vad skulle hända om vi omformulerade frågan så att den i stället handlade om "undervisning i digital sociologi"? Plötsligt skulle några av oss befinna sig i något slags halvt olustigt bindestreckssociologiskt rum. Där vill nog jag placera mig själv eftersom jag undervisar i sociologi under täckmantel - i ett annat ämne, på teknisk fakultet. Jag har ägnat mig åt att tänka sociologiskt kring digitala företeelser så länge jag kan minnas, och mot bakgrund av det kan jag konstatera att den nuvarande situationen på allvar bjuder in till diskussion om vad samhällsförändring kan vara i vår tid. Vad innebär egentligen digitalisering och vad betyder det att vara människa i en värld som också är hemvist för digitala manicker som ägnar sig åt produktion, bearbetning och analys av data som sedan blir till en del av vår värld som digitala strukturer, för att använda ett begrepp jag brukade laborera med som ung student? De digitala plattformar vi möter i vår vardag kan betraktas som "beräkningsmedier" (Berg \& Engberg 2021), eftersom de inte bara förmedlar interaktion utan också använder de data som interaktionen producerar för att forma och anpassa karaktären hos de rum och ytor där människor möts. Det är något som ställer en rad sociologiska grundfrågor på ända och som utmanar vad vi menar med det sociala.

Utöver detta tror jag också att vi erbjuds en möjlighet att diskutera frågor om såväl innovation som relationer mellan företag, det offentliga och det vardagliga som kanske sträcker sig bortom gängse förklaringar och begrepp. Den snabba omställningen till Zoom och distansarbete hade aldrig varit möjlig om vi inte befann oss mitt i en redan ganska mogen digital process, och denna kan tjäna som utgångspunkt för resonemang kring både långsam och genomgripande innovation om man så vill. Samtidigt får vi ganska goda möjligheter att fundera över hur människor och institutioner anpassar sig till teknologier - och hur teknologier i viss mån anpassar sig till dem (eller ja, åtminstone människorna bakom teknologierna). För att återgå till frågan: kanske vi har tvingats undervisa på ett sätt och med ett tematiskt fokus som rimmar bättre med den värld vi lever i. I mitt fall är det många år sedan jag undervisade på en sociologisk institution, men tycker ni andra att samtida undervisning i sociologi tar hänsyn till det digitala i tillräckligt hög grad med tanke på hur digitaliserad världen är? Och kan vi läsa exempelvis klassiker i dag utan att tänka på deras grundfrågor i ljuset av digitaliseringen? 
Ida Lidegran: Mina erfarenheter av att undervisa digitalt har i ganska liten utsträckning handlat om utmaningar vad gäller det sociologiska innehållet. Det är spännande frågor som du ställer Martin, och jag tror att mer publikationer inom sociologi framöver kommer att handla om digitalisering, datafiering och så vidare. Själv har jag tillsammans med mina kollegor ägnat pandemiåret eller pandemiåren åt utbildningssociologiska analyser, som handlar om hur övergången till distansundervisning under covid19-pandemin har upplevts av gymnasieelever. Vi har analyserat dessa olika upplevelser i relation till elevers olika sociala villkor. Slående var att elever redan efter ett par månader av distansundervisning (vi samlade in cirka 4000 enkäter i maj och juni 2020) överlag hade en negativ upplevelse. Olika elevgrupper upplevde dock situationen som negativ på olika sätt. Vi kunde utkristallisera tre olika grupper av elever: elever från en urban övre medelklass, elever med utländsk bakgrund och med arbetarklassursprung samt elever från en rural arbetarklass (Lidegran, Hultqvist, Bertilsson m.fl. 2021).

Undervisningens genomförande har förstås varit en utmaning. Hur varierar man undervisningen digitalt? Hur förändrar man, eller med Basil Bernsteins (1971) ord, hur omkontextualiserar man den pedagogiska verksamheten när studierna förflyttas till hemmet och undervisningen får en svagare "inramning"? Hur klarar olika grupper av elever med olika förutsättningar denna omställning? Påverkades de sociala skillnaderna i utbildningssystemet av den abrupta digitaliseringen av undervisningen, och i så fall på vilka sätt? Frågor av det här slaget har under pandemin varit centrala för oss utbildningssociologer. En viktig lärdom är att den digitala undervisningen landade olika beroende på de olika sociala och digitala villkor som rådde före pandemin.

En annan erfarenhet för mig har varit insikten om att studier är något kroppsligt. Undervisning med studenter IRL innebär ett kroppsligt möte som förmedlar kunskap till mig som lärare om kunskapsinhämtning och bearbetning av innehållet. Nu i tillbakagången till mer campusundervisning har avsaknaden av den kroppsliga dimensionen (inbegripet känslor) under pandemin varit påtaglig. Vilka dimensioner i kunskapsbearbetningen går förlorade när kroppen får begränsat utrymme i undervisningen?

Glenn Sjöstrand: Enligt en rapport utgiven av Universitetskanslersämbetet (Berlin Kolm, Svensson, Bjernestedt m.fl. 2018) har tre av tio heltidsstudenter färre än sex timmars lärarledd undervisningstid i veckan. Över hälften av alla studenter träffar sina lärare mindre än nio timmar i veckan, i sociologi i genomsnitt sex timmar i veckan. Studenterna inom humaniora och samhällsvetenskap (med undantag av vissa ämnen) är de studenter som enligt egen utsago lägger ner minst tid på sina studier (Sonnerby 2012). Detta tror jag är viktigt att ha med sig när vi planerar och genomför digital undervisning som en del av alla undervisningsformer. Med det sagt verkar undervisning $\mathrm{i}$ form av mer traditionella föreläsningar med faktainnehåll fungera väldigt bra digitalt, trots att studenternas reaktioner inte kan avläsas med små kamerabilder eller via frågor $\mathrm{i}$ chatten. Det är liksom svårt att känna av hur de förstår innehållet i stundtals komplexa eller abstrakta teoretiska resonemang. Undervisning i form av aktiva övningar och workshops, där studenterna exempelvis själva ska formulera vetenskapliga problem, teoretisera eller analysera ett visst empiriskt material, kräver i högre grad fysisk närvaro 
i ett klassrum eller åtminstone i Zooms breakout rooms. För att studenterna ska kunna upprätthålla ett mentalt fokus behövs ofta regelbundna korta pauser, men också en variation i undervisningen med diskussionsuppgifter i mindre grupper, quiz eller liknande. Personligen tror jag att det finns didaktiska skäl att arbeta med väl valda inslag av andra aktiviteter även efter det att covid-restriktionerna hävts.

Muntliga framställningar, där man tar hjälp av bildspel, presskonferenser, rollspel, Storyline ${ }^{3}$, kamratbedömningar, omvända klassrum eller övningar där erfarenheterna så att säga "sitter i kroppen", kommer även framöver att bäst genomföras på plats i en lokal där alla fysiskt kan delta med alla sina sinnen. Dessa erfarenheter kan accentueras av multimodal pedagogik, dramapedagogik eller gestaltning. Om läraren kompletterar en webbaserad genomgång eller föreläsning med uppgifter till studenterna, kan läraren skapa sig en bild av vad studenterna förstått och vad de inte förstått. Detta ger läraren möjlighet både att förbereda sig inför nästa möte med studenterna och att utveckla kursen på sikt.

\section{Har ni upptäckt fördelar med digital undervisning, som ni kommer att ta med er när ni undervisar i klassrum igen?}

Glenn Sjöstrand: Redan före pandemin hade många kollegor anpassat sin pedagogik och undervisning till de möjligheter som digital undervisning ger. Då gavs undervisning i hybridform och till del online även på campuskurser. Pandemin innebar att tidigare campuskurser snabbt gjordes digitala utan specificerad tid för anpassning till det nya formatet. Men många kollegor ställde oväntat snabbt och effektivt om till digital undervisning, förmodligen delvis tack vare tidigare erfarenheter, om än med ett ökat antal obetalda arbetstimmar som resultat. Detta gäller förstås långt ifrån alla kurser och kollegor. Men trots allt innebär digitaliseringen att de knappa undervisningstimmarna i något högre grad kan omprioriteras till studentmöten i seminarier, workshops och tillämpningsövningar i klassrummet, förutsatt att den digitala undervisningen planeras på ett effektivt sätt. Trots den omvälvande och snabba omställningen till digital undervisning kunde många kollegor utveckla sin undervisning med många studentaktiva inslag i form av exempelvis videoinspelade föreläsningar, podcasts, en digital anslagstavla som Padlet, interaktiva presentationer i Mentimeter, quiz via Zoom och diskussionsforum, onlinefika utan särskilt program och lärplattformar av typen MyMoodle. Uppfinningsrikedomen och nödtvånget att digitalanpassa även examinationer verkar ha bidragit till högre kvalitet i utbildningen, trots svårigheterna att genomföra dem rättssäkert - och kring frågan om hur examinationer online kan genomföras rättssäkert finns en pågående en diskussion (Herjevik 2020).

Det finns flera skäl till att kurser med lärandemål och anpassade examinationsformer kan bli framgångsrika med inslag av digital undervisning. Jag tror att många upptäckte förtjänsterna med denna typ av undervisning först en bit in i pandemin.

3 Storyline är ett pedagogiskt verktyg som innebär att undervisningen byggs upp kring en berättelse i syfte att öka studenternas engagemang och delaktighet. Red. anm. 
Omställningen ledde förvånande nog bland annat till att studenter i större utsträckning genomgick vissa kurser med godkänt resultat - genomströmningen ökade, åtminstone tillfälligt. Lärarna fick möjlighet att fundera över vilka moment som skulle prioriteras i undervisningen och hur de skulle genomföras på bästa sätt. Studenterna tränade sig i att lära på andra sätt och hitta nya möjligheter till kommunikation med kurskamrater. De goda erfarenheterna ska, som jag ser det, inte kastas bort efter corona, utan användas för fortsatt utveckling av undervisningen framöver.

Resultaten från forskningen om pedagogisk utveckling som berör digital undervisning har förmodligen inte kunnat utnyttjas fullt ut under pandemin, men kanske kan forskningen inspirera fler när vi i skrivande stund är på väg mot färre pandemirestriktioner och undervisningsplaneringen kan få större stabilitet. Att bedriva undervisning digitalt med bibehållen kvalitet har alltså poänger som är värda att ta vara på och vidareutveckla - vi har mycket mer att lära oss.

Martin Berg: Glenn fångar upp en viktig fråga rörande framtiden. Det är helt tydligt att vi har mycket att lära av den snabba omställning till digital undervisning som vi upplevde under 2020 och hur vi under den tid som följde fick en något mer mogen förståelse av de möjligheter och svårigheter vi hade att göra med. Den här situationen har inneburit att vi som pedagoger har tvingats lämna trygga spår för att på allvar fundera över vad vi gör och hur vi gör det på nya och kanske oväntade sätt. Jag har noterat att det finns vissa pedagogiska moment, till exempel grupphandledning som jag ofta inkluderar i kurser, som med fördel kan göras digitalt. Jag kan också konstatera att det finns andra moment som inte alls lämpar sig för digitala sammanhang, till exempel föreläsningar sådana jag ofta vill utforma dem: som utmanande, inkluderande, energiska, humoristiska - något slags edutainment. När detta görs framför Zoom och det enda jag ser är studenter som smaskar i sig sin morgonmüsli - tappar jag i kraft. Dock tror jag att kortare, förinspelade föreläsningar som inkluderas i en omvänt klassrum-pedagogik är en vettig och bra väg framåt.

För att den ska bli framgångsrik krävs dock att vi på ett smart sätt kan koncentrera våra föreläsningar till brottstycken - kanske liknande de faktarutor som är vanliga i läroböcker. Utmaningen blir att bygga ett narrativ som får dessa fragment att skapa en helhet. Det är tydligt att vi har olika förutsättningar beroende på vilken typ av undervisning det är fråga om. Kurser av mer praktisk art kan med fördel rymma den här typen av moment, som frigör mer tid till samtal med studenterna. Det finns dock en risk med allt detta, och det är att vi kanske återanvänder digitalt material lite för många gånger och att ett nödvändigt kontinuerligt pedagogiskt utvecklingsarbete tappar i kraft och fart. Förmodligen och förhoppningsvis lär vi oss även av detta och undviker en situation där vi på grund av sparbeting eller liknande inte blir tvungna att återanvända tidigare föreläsningar. Det är dock en fråga som behöver diskuteras: Hur ska vi tänka kring resurstilldelning för utveckling av den här typen av material, och i vilken mån gäller lärarundantaget när material är att betrakta som beställt av arbetsgivaren (om extra resurser tillförts)?

Jag skulle också vilja peka på möjligheten att använda digitala plattformar för att 
erbjuda kontorstid för studenter. Genom att ha ett fönster i kalendern där studenterna kan nå mig med hjälp av Zoom har jag dels sluppit en lång rad e-postmeddelanden, dels sluppit att i onödan befinna mig på "kontoret" (vid Malmö universitet har dessvärre inte ens professorer egna arbetsrum) för möten som eventuellt aldrig blir verklighet. Det här är något jag har för avsikt att fortsätta med, inte minst under perioder då jag är på resande fot. På så sätt blir det möjligt att respektera kollegors dyrbara arbetstid.

Ida Lidegran: En förutsättning för att få i gång undervisningen digitalt var att fungerande digitala plattformar fanns på plats. I Uppsala var Zoom centralt för övergången till distansundervisning. I ett första skede handlade mycket om att utforska denna plattforms möjligheter och begränsningar. Allt eftersom har fler plattformar och verktyg blivit aktuella. Jag har "tvingats" lära mig flera nya verktyg i den lärplattform som vi använder vid Uppsala universitet (självrättande quiz, muntliga presentationer som studenterna spelat in och så vidare). Jag upplever att den pedagogiska verktygslådan helt enkelt har utökats men så länge man inte kan undervisa på campus kan dess fulla potential inte realiseras. Att utforma muntliga examinationer och uppgifter har hamnat högre upp på dagordningen sedan det visat sig att skriftliga examinationer öppnat upp för fusk. Som Martin beskriver har lärartillgängligheten kunnat effektiviseras och delvis omdirigeras. Jag håller helt med om beskrivningen av svårigheterna kring hur inspelade föreläsningar ska användas och problematiken med resurstilldelningen. Vi spelade in ett antal föreläsningar (redan före pandemin) som vi ansåg vara användbara över tid och som sammanfattade mycket av lärarnas kunskaper. Jag tror att vi med fördel kan utveckla olika typer av inspelade föreläsningar, där vissa är kortare och föränderliga och andra mer hållbara. Det krävs dock att man tänkt igenom hur man ser på användningen av föreläsningarna, så att de inte bara återanvänds per automatik.

Ulrika Schmauch: Jag är väldigt ambivalent till digital undervisning. Å ena sidan har det fungerat förvånansvärt väl att undervisa digitalt. Studenterna har fått se föreläsningar på det sätt de själva haft mest nytta av och kunnat se och höra dem flera gånger. Undervisningen vid seminarier och workshops har blivit mer effektiv och kunnat fokusera på väsentligheter. Studenter med små barn har haft möjlighet att vara med vid frågestunder och lyssna till presentationer, trots att barnen inte alltid kunnat vara på förskolan. Att hålla muntliga presentationer har varit lättare för de studenter som kan gömma sina nervösa armar eller ben undan kameran. Jag tänker mig att jag även framgent kommer att spela in föreläsningar och ha kortare undervisningsinslag digitalt, till exempel frågestunder och kortare workshops, och låta studenter träna på olika typer av muntliga framträdanden. Men även om den konkreta undervisningen fungerat bra, finns det också en rad utmaningar.

En svår sak har varit att fånga upp de studenter som inte gör så mycket väsen av sig och som riskerar att hoppa av utbildningen utan den extra peppen från lärare och kurskamrater. Inte sällan handlar det om studenter med låg representation i utbildningarna, rasifierade studenter, studenter vilkas föräldrar inte studerat vid universitet och studenter med olika typer av funktionsnedsättningar. Många studenter har mått 
dåligt när de själva behövt hitta strategier för att planera sin undervisningsfria tid. Svårigheten att "läsa av" hur formuleringar vid seminarier upplevs av andra studenter gör det också svårt att som lärare till fullo använda diskussionerna som pedagogiskt verktyg.

Mer konkret tänker jag mig att det kommer att ta ett tag innan jag som lärare gjort den större verktygslådan, som Ida nämnde tidigare, till min och fått en känsla för vilken typ av verktyg som får vilka konsekvenser i olika kurser, för olika grupper av studenter och i min egen vardag som lärare.

\section{Den digitalisering som många sociologiska institutioner snabbt fick ställa om till under våren 2020 kan ses mot bakgrund av informationssamhällets expansion. På vilka sätt har denna expansion påverkat hur vi undervisar i sociologi i dag?}

Martin Berg: Det är inte ovanligt att vi går tillbaka till idén om informationssamhället som en stabil referenspunkt när vi försöker förstå samtiden, men vi glömmer lätt att vi har att göra med tankar som är ganska daterade (sent 1990-tal och tidigt 2000-tal). Det är lite olyckligt med tanke på den ganska intressanta roll som teknologier har haft för den sociologiska praktiken under alla år. Jag tänker på hur mina äldre lärare i Lund muttrade, halvt besvärat, halvt lyriskt, om tiden då hålkortsbaserad databearbetning var på tapeten. Tänk så mycket av den sociologiska praktiken som då kretsade kring maskiner, att förbereda data för dem och så vidare! Som jag pekade på tidigare tror jag att vi behöver vara tydliga med vad som egentligen är annorlunda i dag. I stället för att använda informationssamhället som referenspunkt tror jag att vi behöver finna andra begrepp som bättre fångar hur digitala teknologier av olika slag fått en central betydelse för människors vardags- och yrkesliv. Digitalisering väcker en rad frågor om vad det innebär att vara människa i dag - ensam såväl som tillsammans med andra, vad fritid kontra arbete är, vad gemenskap är, vad nöje är, hur vi formar oss själva. Listan kan nog bli snudd på oändligt lång. Denna förskjutning mot vardagslivet torde få betydelse för hur vi undervisar såväl teoretiskt som metodologiskt. Sannolikt behöver vi fundera på inte bara hur vi praktiserar sociologi i och om det digitala, utan också hur vi praktiserar sociologi digitalt - något som kräver att vi forskar både om och med internet (Berg 2015).

Ida Lidegran: Jag har under flera år undervisat på distanskurser i utbildningssociologi, och digitaliseringen av min undervisning har utvecklats efter hand. En spaning jag gjorde tidigt var att studenter som valde distansundervisning inte bara ville vara oberoende av platsen utan också av tiden. Jag hade föreställt mig att distansundervisning bara handlade om platsflexibilitet. Denna vana vid att själv kunna välja var men också när man vill göra olika undervisningsmoment är, tänker jag mig, en del av informationssamhällets expansion - att var som helst och när som helst kunna checka in och checka ut från flödet. Kraven på flexibilitet i tid och i rum innebär att undervisningen får en annan rytm och en annan typ av inramning än traditionell på-plats-undervisning. Jag har insett att mina undervisningsmoment styckas upp i mindre delar med fler och 
delvis andra typer av bedömningsmoment och bedömningsformer. Det blir lite som en snitslad bana med olika kontrollstationer. Detta innebär en risk för att helheten går förlorad och att bildningsidén blir underordnad andra rationaliteter, som att få snabb återkoppling på att man klarat olika moment. Det kollektiva kunskapandet försvagas till förmån för en mer individuell kunskapsprocess.

Ulrika Schmauch: När jag började undervisa för ungefär femton år sedan hade jag kurser där studentgruppen var uppdelad mellan två orter. Jag och några studenter träffades i Sundsvall och en annan grupp studenter var med via länk i Östersund. Precis som Glenn var inne på tidigare var hybridundervisningen energikrävande. Att skapa en relation med studenterna som befann sig långt borta var svårt, och jag upplevde ofta att jag relaterade till studenterna i Östersund som en anonym massa, trots mina ambitioner att det inte skulle bli så. I möjligaste mån försökte jag därför träffa båda studentgrupperna IRL tidigt under kursen, inte minst för att de skulle känna sig trygga med att ställa frågor, säga till om tekniken inte fungerade och så vidare.

När vi 2020 övergick till digital undervisning fanns det tekniska förutsättningar för att interagera med studenter på ett jämlikare sätt, och studenterna hade också redan träffat mig och varandra vid ett flertal tillfällen. Jag är osäker på hur detta såg ut på andra universitet, men i början av pandemin hade vi campusundervisning för nybörjarstudenter, medan äldre studenter hade undervisning på distans. Att genomföra undervisningen på distans blev visserligen en stor omställning, men undervisningen var relativt lik den undervisning som ägt rum på campus tidigare. Under senare terminer, när studenterna varken träffat mig eller varandra och inte heller alltid befunnit sig i samma stad, har det varit viktigare att anpassa formerna för undervisningen. Situationen har skilt sig från den traditionella distansundervisningen, där studenterna ofta vill ha tidsflexibilitet, som Ida var inne på. Här gällde det ju att få till stånd en undervisning där studenterna närvarade vid de undervisningstillfällen som fanns och där det skapades ett tryggt klimat och en klass- eller programkänsla.

Glenn Sjöstrand: Martin var i sitt inlägg inne på att tekniken historiskt sett haft betydelse för undervisningens praktik och att digitaliseringen väcker frågor om vår existens. Så är det säkert, inte minst för lärare i tider av snabb anpassning till teknikens möjligheter och begränsningar. Vi har nog alla varit särskilt stressade inför en kursintroduktion där vi måst förlita oss på att tekniken fungerar och kanske haft en kollega från IT-avdelningen på snabbval i telefonen för säkerhets skull, hur väl vi än förberett innehåll och presentationer i Keynote eller Powerpoint. I vilket fall är vi helt i händerna på tillgänglig och fungerande teknik och vår egen (bristande) kompetens att få den digitala undervisningen att fungera som vi vill, ofta utan att känna till teknikens fulla potential - den kompetensen får man möjligen längre fram genom att gå en särskild kurs om allt man kan göra i lärplattformar, i Excel eller via våra mobilappar designade för studenternas gränssnitt. Numera är "sakernas internet", sensorer, oändlig digital information och den så kallade hyperkonnektiviteten (Brubaker 2020), där alla kan vara uppkopplade mot alla, en del av samhällets förändring som vi känner den. Infor- 
mationssamhället har rört sig vidare mot något mer allomfattande, som vi sociologer säkert kan bidra till en bättre förståelse av.

Studenter som är födda på 2000-talet är en digital generation som vet att det finns information att hitta i den digitala verkligheten och som ofta vet att använda den - ibland på ett legitimt, ibland på ett icke-legitimt sätt (antalet anmälningar till disciplinnämnderna har ökat under pandemin). I dag kan vi förutsätta en större förtrogenhet med digital information och teknik bland studenterna. Det gör förmodligen att studenterna ställer högre krav inte bara på sofistikerad digital undervisning utan också på alltmer frekvent sådan - något som jag själv har erfarenhet av - kanske till den grad att det blir svårare att rekrytera studenter till kurser av traditionellt slag utan särskilt mycket blandade lärmiljöer eller helt förlagda till campus. Men därom lär vi bli varse inom en snar framtid.

\section{Som lärare i sociologi förväntas vi väcka studenternas intresse för samhället. Hur tycker ni att vi reagerar på och tar oss an aktuella samhälleliga förändringar, som covid-19-pandemin, när vi undervisar i sociologi? Hur ska vi undervisa om samhällsförändringar som vi står mitt uppe i?}

Ida Lidegran: Detta är förstås inte alltid lätt, men en kurs vi ger i utbildningssociologi heter "Utbildning och samhällsförändring". Inom denna kurs tar vi upp digitalisering som ett tema. Digitaliseringstemat har varit tacksamt att knyta till pandemin under kursens gång. I början av pandemin tyckte jag att det var svårare att ta in covid-19-pandemin i undervisningen, då man inte riktigt visste hur den hade drabbat studenterna och deras familjer. De senaste två terminerna har det varit lättare och självklarare att koppla olika sociologiska frågor till förhållanden under pandemin. Teman vi har behandlat är globalisering-pandemi, digitalisering-pandemi och social ojämlikhet-pandemi. Frågan om vad som är stabilt är viktig att ställa när samhällsförändringar studeras och diskuteras.

Glenn Sjöstrand: I undervisningen för ingenjörer, som jag nämnde tidigare, ingick ett moment om hur teknologiska innovationer och processer får genomslag i samhället eller ej. Det handlade om aspekter på teknologins inbäddning i olika sociala strukturer och institutioner i samhället. I det sammanhanget är ju den pågående pandemin ett bra exempel på hur vetenskap i allmänhet och medicinsk vetenskap i synnerhet uppfattas som förtroendeingivande eller ej. Vilka grupper i samhället förlitar sig på nya mediciner och tar sitt vaccin och vilka gör inte det? Vad beror det på att vaccinationsgraden skiljer sig mellan olika samhällsgrupper? Med den typen av relativt öppna frågor kan studenterna relatera till den pågående samhällsdebatten på temat och dessutom relatera till hur de själva eller närstående resonerar.

Exemplet med pandemin kan öppna för frågor som handlar om a) hur hanteringen av pandemin formar och formas av sociala, politiska och ekonomiska omständigheter och förändringar; b) hur pandemin tydliggör intersektionella skiljelinjer inom och mellan kön, klass, etnicitet, plats och ålder; och c) hur användningen av digitala verktyg är 
en del av den teknologiska hanteringen av pandemin och hur den påverkar relationen mellan individ och samhälle i fråga om exempelvis integritet, deltagande, övervakning, etiska förhållningssätt, produktion och konsumtion av sjukvård och medicin samt hur den kan relateras till pandemins politiska ekonomi.

I undervisningen för ingenjörerna formulerades denna typ av frågor för vidare funderingar med tanke på ingenjörsprofessionernas förutsättningar, men också i syfte att uppmuntra ett kritiskt förhållningssätt dels till teknologins roll i samtida samhällsutmaningar, dels till olika perspektiv på teknologin och den digitala utvecklingen. Några svar förväntades inte i sammanhanget, men att över huvud taget formulera sådana frågor i utbildningen för studenter som i sitt framtida yrke ska arbeta med att lösa verkliga samhällsproblem är en bra början.

Ulrika Schmauch: Eftersom sociologi i hög grad handlar om att "främmandegöra det vardagliga" (Bauman \& May 2004) var pandemin, framför allt i början, ett bra exempel som kunde hjälpa studenter att få syn på vilka delar av tillvaron som påverkas av samhället omkring oss. Eftersom åldersskillnaden mellan studenterna och mig blir allt större har vi också lite olika referensramar när det gäller samhällsförändringar. Jag minns Berlinmurens fall och början av kriget mot terrorismen, men för många studenter är det något som hände "förr". Många studenter har svårt att relatera till samhällsförändringar på ett djupare plan. Pandemin har haft den pedagogiska fördelen att förändringen ägt rum snabbt och i flera olika sektorer samtidigt, så att det är relativt enkelt att få syn på ett "före" och ett "under" pandemin. Den är också ett tydligt exempel på politikens möjligheter att förändra eller sätta gränser för våra sociala relationer.

En annan upplevelse av detta är att jag som lärare behöver anpassa undervisningen olika mycket för olika studentgrupper. Jag har under flera år undervisat på en kurs om ledarskap och professionsutveckling på fysioterapeutprogrammet. Vi har ett seminarium där vi bland annat diskuterar hur organiseringen av arbetet inom primärvården ser ut. För de studenter som gjort sin VFU (verksamhetsförlagda utbildning) inom primärvården under pandemiterminerna har pandemin framför allt förändrat relationerna mellan kollegor, eftersom möjligheterna att fika tillsammans varit begränsade, personalmötena varit färre och så vidare, medan kontakterna med patienter i stort sett varit oförändrade jämfört med tidigare terminer. De diskussioner som kommit upp kring pandemin har handlat om betydelsen av den organisatoriska omvärlden och på vilket sätt den känns av inom olika delar av arbetsmarknaden. Det har varit tydligt att arbetet med patienterna inte påverkats i någon större utsträckning. För de studenter som läser teoretiska utbildningar (till exempel sociologi) blir förändringen av studentvardagen förstås mer omfattande, eftersom de haft små möjligheter att träffas för mer informella samtal om kursinnehållet.

Martin Berg: Det är här en viktig och knepig fråga. I mitt pedagogiska tänkande hämtar jag ofta inspiration från vad Paul Hanstedt (2018) benämner "wicked students" och vikten av att konstruera kurser och pedagogiska moment som sätter studenternas vardagserfarenheter i centrum. Tanken är att rusta dem för en värld där de inte bara behöver 
kunskaper, utan också förmåga att på egen hand ställa frågor till, delta i och utmana den värld de möter och dess "lömska problem". Detta yttrar sig i att jag ofta bygger min undervisning och examination på frågor som studenterna själva får utveckla och utvärdera. De lär sig att ta ansvar inför sig själva och sätta ord på sina erfarenheter och iakttagelser genom att göra dem till en vetenskaplig angelägenhet som används i det gemensamma lärandet. Eftersom jag främst undervisar i medieteknik - om än med en tydligt sociologisk klangbotten - har detta främst yttrat sig i ett fokus på kritisk granskning och diskussion av de medier och digitala teknologier med hjälp av vilka vi lever våra liv och de föreställningar som omgärdar dessa på olika nivåer (Fors, Pink, Berg m.fl. 2020; Pink, Berg, Lupton m.fl. 2022). Detta är något som vi alltid gör i mitt ämne, men det har varit enklare och uppfattats som mer angeläget under pandemin, då delar av livet kommit att medialiseras med en hastighet som få hade kunnat ana.

\section{Referenser}

Aytar, O. \& O. Mella (2012) "Bortom skolframgång. En analys av PISA 2006 ur ett intersektionellt perspektiv", Sociologisk Forskning 49 (1):45-65.

Behtoui, A. (2017) "'Främlingen' bland svensk 'Homo Academicus'”, Sociologisk Forskning 54 (1-2):91-110.

Bauman, Z. \& T. May (2004) Att tänka sociologiskt. Göteborg: Korpen.

Berg, M. (2008) Självets garderobiär. Självreflexiva genuslekar och queer socialpsykologi (doktorsavhandling). Lund: Sociologiska institutionen, Lunds universitet.

Berg, M. (2011) "Checking in at the urban playground. Digital geographies and electronic flâneurs", 171-196 i F. Comunello (red.) Networked sociability and individualism. Technology for personal and professional relationships. Hershey: Information Science Reference. https://doi.org/10.4018/978-1-61350-338-6.ch009

Berg, M. (2012) "Där tran(s)orna slutar dansa. Facebook och den andres automatisering”, 93-113 i J. Mjöberg \& A. Lundin (red.) En gestalt, många berättelser. En vänbok till Lars-Erik Berg. Skövde: Institutionen för teknik och samhälle, Högskolan i Skövde.

Berg, M. (2014) "Participatory trouble. Towards an understanding of algorithmic structures on Facebook", Cyberpsychology 8 (3):2. https://doi.org/10.5817/CP20143-2

Berg, M. (2015) Netnografi. Att forska om och med internet. Lund: Studentlitteratur.

Berg, M. \& M. Engberg (2021) "Beräkningsmedier", 261-269 i P. Falkenberg Josefsson \& M. Wiberg (red.) Introduktion till medieteknik. Lund: Studentlitteratur.

Berlin Kolm, S., F. Svensson, A. Bjernestedt \& A. Lundh (2018) Lärarledd tid i den svenska högskolan. En studie av scheman. Rapport 2018:15. Stockholm: Universitetskanslersämbetet.

Bernstein, B. (1971) "On the classification and framing of educational knowledge", 363-392 i R. Brown (red.) Knowledge, education, and cultural change. Papers in the sociology of education. London: Routledge. https://doi.org/10.4324/978135101814213 
Brubaker, R. (2020) "Digital hyperconnectivity and the self”, Theory and Society 49 (5-6):771-801. https://doi.org/10.1007/s11186-020-09405-1

Bruno, L. (2012) "Pedagoger i det sociala uppdragets gränstrakter. Att hantera familjerättsliga processer, hot och våld", Sociologisk Forskning 49 (3):189-210.

Collins, R. (2020) "Social distancing as a critical test of the micro-sociology of solidarity", American Journal of Cultural Sociology 8 (3):477-497. https://doi.org/10.1057/ s41290-020-00120-z

Fors, V., S. Pink, M. Berg \& T. O’Dell (2020) Imagining personal data. Experiences of self-tracking. London: Routledge. https://doi.org/10.4324/9781003085676

Goffman, E. (2020[1959]) Självframställning i vardagslivet. Lund: Studentlitteratur.

Hansen, L., T. Johansson, A.-K. Kollind, P. Månson \& L. Svensson (red.) (1997) "Sociologi i tiden. Bakgrund, utveckling, framtid". Sociologisk Forskning 34 (1-2).

Hanstedt, P. (2018) Creating wicked students. Designing courses for a complex world. Sterling: Stylus Publishing.

Herjevik, M. (2020) Rättssäker examination. Fjärde upplagan. Stockholm: Universitetskanslersämbetet.

Ismail, E. (2011) "Elitutbildning: en strategi för erkännande? En studie om anti-diskrimineringsstrategier bland juriststudenter med ursprung i Mellanöstern”, Sociologisk Forskning 48 (4):5-24.

Lidegran, I., E. Hultqvist, E. Bertilsson \& M. Börjesson (2021) "Insecurity, lack of support, and frustration. A sociological analysis of how three groups of students reflect on their distance education during the pandemic in Sweden", European Journal of Education Research, Development and Policy 56 (4): 550-563. https://doi. org/10.1111/ejed.12477

Pink, S., M. Berg, D. Lupton \& M. Ruckenstein (red.) (2022) Everyday automation. Experiencing and anticipating emerging technologies. London \& New York: Routledge. Sonnerby, P. (2012) Lärda för livet? En ESO-rapport om effektivitet i svensk högskoleutbildning. Stockholm: Finansdepartementet. 